\title{
Traceability model system as originality assurance method for honey product, Indonesia
}

\author{
Jaisy Aghniarahim Putritamara
}

Socio-economic livestock department, Faculty of Animal Science, Universitas Brawijaya, Indonesia

Email: jaisyap@ub.ac.id

Rahmi Yuniarti

Industrial Engineering Department, Faculty of Industrial Engineering, Universitas Brawijaya, Indonesia

Email:rahmi_yuniarti@ub.ac.id

Anie Eka Kusumastuti

Socio-economic livestock department, Faculty of Animal Science, Universitas Brawijaya, Indonesia

Email: anieka_05@ub.ac.id

\section{Abstract}

Honey is a hype product as immunity booster in the health shock covid-19. Unbalance of supply and demand has raised the price and made the consumer could not afford it. Besides that, global issue about unoriginal honey which spreads in society has made the consumer has negative stigma on SMEs honey product because it does not have complete food safety certification as commercial company. Objective of the research was to increase the consumer trust through originality assurance for honey product from traceability system. The research is a case study with FGD method and then followed by Interpretive Structural 
Modeling (ISM) analysis and Business Process Notation as solution. Result of the research showed that the distribution aspect has great power to affect the stakeholder and logistic aspects, due to success of both aspects are determined by distribution aspect. While the stakeholder aspect does not have any power to affect other aspect because if the business system has correct SOP, then both aspects will have appropriate supply chain management. Therefore, the solution is business process improvisation, so that to increase the trust local brand for honey product, it must be optimized through recording system of customer journey, so that the producer could trace the barrier and enabler factors about perspective of the honey originality..

Keywords: Distribution, Honey, Originality, Stakeholders, Traceability.

\section{Introduction}

During the pandemic of covid-19, the consumer awareness to consume nutritious food products has increased. They consider deliberately purchasing the product based on the health aspect. One of them is the great contribution of livestock sector as provider of high nutritious foods and plays as immunomodulatory, which is required by community to support their health, so that the consumer demand for livestock product is increasing. The pandemic era has changed the consumer behavior to be more selective to choose the food products. If we study about the trend of food products, the herbal products have increased during pandemic. This is in line with the government's appeal regarding health protocols to wear masks, social distancing, and maintain the immune system, so that it will establish new community activity that makes herbal products or supplements become the mainstay products as immune booster. The product becomes the target of household needs per capita after the primary food. One of the livestock products that contains high micronutrients and increase the immune system is honey.

Honey is a hype product during pandemic because it becomes supplementary needs for consumers to support their health after primary products. The health experts explain that increasing the immune is affected by digestive condition for about $70 \%$, if condition of the digestive tract is good, the immune system will increase. This is in line with composition contained in honey, namely prebiotics fructooligosaccharide (FOS) as good object for digestive bacteria, besides that honey contains antioxidant, polyphenol and 
flavonoid that are needed by the body.

The trend of buying honey is increasing drastically and it provides an opportunity for honey producer to increase consumer satisfaction in order to survive during the health shock. The era of modern technology and health shock factor have made the consumer to be more selective to choose honey product of the preferred brand. For certain group of community who have decreased purchasing power, they will choose products with affordable prices, while for consumers who have stable purchasing power, they still purchase honey even if costly, but they have received positive recommendations from consumers. Based on information from Susenas (Central Bureau of Statistics, 2018) in 2017 whereas the millennial communities were 88 million or 33.75 percent out of the Indonesian populations in which the majorities were generation $\mathrm{Y}$ and $\mathrm{Z}$. The consumer characteristics in digital era are more selective against the product assessment. More native digital than immigrant digital has positive chance for development of the livestock business, which is accidentally as producing sector of food product because the millennial consumers have great power in decision-making to purchase. It also has negative effect in which the customer recommendations become the center of attention and consideration to purchase the product. If the consumers are disappointed toward their purchased product, so that they will express their dissatisfaction to 10 persons, but if they are satisfied, they will express positive recommendations to 5 prospective consumers. During health shock, food manufacturers should increase their alertness to avoid any disappointment when they design a product and its attributes to be more adaptive that conform to the consumer expectation and desire.

According to Sciffman and Winsenblit, consumer behavior is defined as a study that relates to tracking and tracing the consumer action during they are searching, purchasing, using, evaluating, and deciding to repurchase or stop (Sciffhman and Wisenblit, 2015). This study describes how individual determines the available resources, so that the purchasing power determines a producer/ manufacturer to design a product. In this study, producer considers the product design by observing product, which mostly purchased by the consumers, factors that determine decision-making to purchase the product, when the product is purchased by the consumer, where does the consumer mostly purchase the product, recording the purchasing frequency of the consumer, frequency of the product consumption, method used by the consumer to evaluate the product, and consideration about what the consumer has to stop consuming the product. 
The study becomes the parameter for producer to find out consumer journey, which affects on business continuation. Product that has good brand image will always attract the consumer attention. However, producers really expect to have the same market share, particularly for honey product. Up to now, a number of consumers still put in doubt the originality contained in honey product, and it is susceptible to negative issue about originality of the product. For certain consumers, honey is not a primary food. Honey is a supplement to increase immune system. For consumers who are critical to product assessment, they have more knowledge about honey, so that they would not be easy to trust to the whole honey producers, because the product could be adulterated easily. Few producers remove honey originality to gain more profits, such as producing synthetic honey (caramelized sugar liquid with a honey-like texture) and syrup honey that derived from bees, which consume sugar water (not nectar) so that if it is tested, it contains 50\% sugar and 50\% honey. Certain producers who replace composition of pure honey with synthetic sweeteners from fructose may endanger the consumers because the product will trigger diabetes and increase cholesterol level from LDL. Besides originality of honey, other factor that triggers whether the honey is original or not is the supply chain of honey product. Therefore, to increase trust and credibility of the honey brand, traceability system is required as originality assurance method.

SMEs is the business level, which is the most affected when credibility of a product becomes the main point of the consumer in deciding to purchase the product. During pandemic, the whole business elements strive to survive in order to develop their business in the midst of uncertainty due to health shock of covid pandemic. Honey product is perishable food and when the government urges the community to stay at home and restrict activities outside, so that it inhibits honey distribution and automatically it reduces product absorption. Massive impact of the pandemic on consumer purchasing power has forced producers to compete with each other strictly for the market. If honey product from SMEs is compared with commercial honey, SMEs requires specific strategy to survive in order to increase the consumer trust. Selective behavior of the consumer has triggered SMEs to be more transparent and adaptive to the consumer needs today. Such selectiveness is not only caused by the consumer behavior in modern era, which is adaptive to technology and information, but also the consumer consideration to get product based on priority scale due to low purchasing power of the consumer as a result of economy crisis.

Change in consumer behavior consists of individual behavior and 
mindset, while change is defined broadly as change in social structure that will affect social development in the future. Massive change is also well-known as reformation (Nurmalia et al., 2019). Impact of such change that can be perceived by the community is the economy aspect. It is due to each community decides to purchase based on their needs. If an economic change occurs in a country, its impact will affect on the community concerning with fulfillment of their needs whether decrease or increase (Nurmalia et al., 2019). A change is a condition that cannot be avoided due to strong urge of external condition along with individual internal needs (Arifah, 2020).

Based on the described problem above, the author initiated to increase consumer trust and facilitate the supply chain activities by increasing transparency of honey product from upstream to downstream through traceability system, so that the consumer will be able to access directly the information about agrobusiness from bees to honey product at the hand of end consumers. Besides that, the producer will be easier to monitor development of the consumer change in order to produce an adaptive product in accordance with the consumer needs at that time. The producer fraud is imitating a product as the original one due to no transparency of marketing institution, which should inform the product line from upstream to downstream. Therefore, in order to increase integrity of honey originality, traceability in Supply Chain must be applied as effective method to assure originality of honey product as contribution to food security during crisis (Iwan, 2017).

By the application of traceability system, a company will be able to identify the product lot that relate to batch of raw materials, processing, distributing the product and logistics, so that it will minimize withdrawal of the whole product lots, which had been produced. Traceability system also establishes a company to increase competitive advantage through ability in documenting the offered product characteristics (Olsen and Borit 2013).

The research used Interpretive Structural Modeling (ISM) to obtain traceability modeling system for originality assurance of honey product. A number of experts who observe food product assurance, also applied this method to assure that the food products are kosher (halal), but in this research, the author has concerned with originality (Yang \& Bao, 2011)

ISM method is designed systematically to describe the structure of complex problems comprehensively due to the formed elements were resulted from FGD and the experts (Banwet \& Shankar, 2006). Besides that, ISM method is also used to determine complex relationship among elements that 
have been designed by the experts in an assessment system using Exsimpro software (Pfohl, et.al, 2011).

Some previous research used ISM method to reduce operational risks and supply chain, which were caused by barrier factors because they were not relevant to the system. This method was also designed by food manufacturers to increase consumer satisfaction (Bahadori and Teymurzadeh, 2018). ISM also assists the producer to identify and create critical barrier model against SMEs business, so that the business will be more adaptive (Gardas, et.al, 2018). Therefore, the author chose ISM system because it is quite representative to measure complexity in marketing institution for honey product to monitor its originality. In early stage, the selected experts determined the crucial elements in supply chain of honey product that related to traceability of honey originality in order to increase credibility of local brand in SMEs level.

The novelty of this research showed that so far there is no originality assurance of honey product. Consumer credibility toward honey product is higher on commercial with complete assurance for food, so that the consumer trust is higher, however, more honey products from SMEs business produce original honey, but based on the consumer perspective, the credibility is still lower because there is no consumer assurance method for product originality from upstream to downstream.

The first paragraph in each section should be left-aligned and each following paragraph should be indented. Text should be single-spaced with no space between paragraphs.

\section{Literature Review}

\section{Consumer Behavior towards Honey Product}

The pattern of honey purchasing decisions is based on consumer demographic factors. All segments decide to buy honey with consideration of authenticity, nutritional content, positive impact from health and hygiene aspects. Kotler \& Keller (2012) that consumer trust has an impact on the consideration of other consumers to decide on a purchase. The company relies on consumer trust as a marketing referral to increase the trust of other consumers.

\section{Traceability}

Consumers in the crisis period have the main consideration in purchasing 
products related to product safety. This is a determining factor for consumers to rise at the level of purchasing decisions. Traceability is a solution to improve purchasing decisions. European Union countries use the traceability system as a guarantee for food products Kementerian Perdagangan, 2015). The traceability system has 2 main performances, namely tracing and product tracking. The traceability system is optimal if the producer has a record of product flow from upstream to downstream. The technology needed in tracking and tracing starts from procurement, production processes, distribution, packing and labeling (Handayani 2014). Traceability systems help companies improve business performance through product lot identification systems and their relationship to raw material batches, processes, and product delivery processes. This system also gives companies a competitive advantage through documenting product characteristics (Olsen and Borit 2013).

\section{Methods}

The research was conducted at Agro tawon Rimba Raya for 2 months from April to June 2021 through survey method, FGD from case study. Agro Tawon Rimba Raya is producer in the field of various livestock agribusiness that concerns with bee breeding, which is integrated with tourism sector, so that the producer initiates the business model in the form of agro edu-tourism.

The research locates at Lawang District of Malang Regency. Location of the research was determined using purposive method. It was selected as object that belongs to producer category, which develops business of honey products from upstream to downstream. Objective of the research was to trace product originality at the marketing institution level in order to increase consumer trust in local brand. The initiated downstream optimization is transparency of honey product originality in agribusiness system (upstream to downstream) and then followed by improvement of business system to increase consumer credibility on local product of Agro Tawon Rimba Raya. Issue about imitated honey product made the consumers to be doubtful and lead to low consumer trust, particularly for SMEs products. As a result, the producers could not improve the marketing strategy due to the designed tactic will be bias with negative recommendation from consumer because of low consumer trust. The impact is consumers prefer supplements from other commercial producers to meet their needs for honey, and even prefer products that are more practical in the form of processed products such as encapsulation rather than having to consume fresh honey and other products such as propolis, honey comb, bee pollen, and royal jelly. 
The research used explanatory research with case study method on bee producers. Yin (2003) suggested that case study is basically intended for analytic generalization (level one inference) in which findings of the case study were measured in relation to the extent of its contribution to the development of theory. Objective of explanatory method focused on topic of the research, which will become the liaison between producer and consumer information to increase product value, especially in terms of product originality and data transparency, as well as information in downstream sector. During pandemic, SMEs in bee agribusiness sector will compete to develop resilient business through traceability optimization strategy of honey product.

Samples were collected through in-depth interview with the breeder, processing, the involved marketing institution and end consumer. Data collecting process was started from determining the experts, namely the actors involved in originality assurance of honey product, and then followed with FGD to determine elements in accordance with agreement of the experts, ISM analysis, data interpretation and traceability model implementation, and then improve business system that conforms to the current problem. During the research, FGD was intended to determine relevance of the elements of the stakeholder decision and prospecting consumer as a design for recording the consumer behavior and trust to local product.

Upstream-downstream observation includes identity of the producers, the involved marketing institutions, stakeholders who get involved in supply chain activities and logistic traffic. Product identities include name of the stakeholders, business name, type of business, business license number, e-mail address, link website, item code, types of goods, time for receipt of goods, delivery time, coordinate or location of the agency/reseller. For bee breeders, identity is almost the same as stakeholders, only upstream and on-farm information is added. Queen bee code, types of tree, cultivation cycle, feed, maintenance, and harvesting are concerned, so that the producer will be easier to trace the chain of product values and consumers will be assured for the product originality.

Method of the research used action research, which means that the researcher describes, interprets, and explains a social phenomenon. Following the research, the researcher tries to intervene and result positive change, so that result of the research will be applied directly to get the impact. According to Davison, Martinsons and Kock (2004) data analysis used Interpretive Structural Modeling (ISM) approach to design traceability system model for originality assurance of honey by involving supply chain management. ISM analysis is a 
representative decision-making analysis that conforms to the existed problem by describing elements of the traceability system, which has been agreed by the experts during FGD. After that, the experts will determine correlation among elements in current condition to be a model that will be analyzed. The resulted model will be used to build ideas and solutions against problems, which were faced by the producers.

After being analyzed using ISM to obtain model and solutions of the emerged problems, it will be continued with Business Process Model Notation (BPMN) analysis to improve the business. Business Process Modeling Notation (BPMN) is a business modeling that provides notation to describe standard of business process. BPMN modeling used flow chart technique that is assembled to form graphical model, which relate to business operational and flow control to describe job description (Yohana, 2018). Objective of BPMN analysis is providing adaptive notation in order to be easily used and understood by all individuals who get involved in business. So that everyone who get involved in diverse managerial levels should be able to read and comprehend quickly the process of diagram, therefore it is expected that it will be able assist in decisionmaking process.

\section{Results and Discussion}

Tawon madu Rimba Raya (TRRL) is the producer in honey agribusiness. Business system is developed through integration with education-based tourism sector. The main product of TRRL is pure honey, which is produced from some species of bees, and one of them is Apis mellifera, bee pollen product, propolis, and some other honey products. The best seller honey is bee pollen infection as immunity booster and pure honey. Nevertheless, the issue of artificial honey and syrup honey has lessened the consumer trust toward local product and its impact on the producer income.

\section{Originality and Traceability Element of Honey}

Honey originality becomes global issue due to high supply and demand. Consumers who do not understand the characteristics of honey, are susceptible to getting products at lower prices or even the same but of low quality because they are made from synthetic honey, mixed and syrup honey that contain 50\% original honey and $50 \%$ supplemental feeds for bees, which are given by the breeder when the flowers do not bloom so that when harvesting the honey, its content is not pure. If previously the problem of honey originality was in the 
distribution process, however, high demand and supply, competition among competitors is getting tougher in the face of the market, therefore it requires traceability from upstream to downstream. Particularly when covid-19 breakout, the peoples have panic buying which leads to imbalanced market and even unpreparedness of producers in the face of economics and health shock. So that production capacity and the demand become unbalanced. If the demand is higher than product availability, the price will raise. If such phenomenon continues, the prices will raise but the purchasing power of the consumers will decline. Such phenomenon is used to be experienced by during massive crisis whereas the peoples are worried as they could not fulfill their needs and do not afford to purchase the products when the prices rise. Such cases mostly happen on food products which are categorized as primary needs.

Agricultural sector is superior sector that produces food products. When pandemic is breakout, the agricultural products increase drastically. Before the economics shock as a result of pandemic, the Indonesian consumers still afford to fulfill their primary needs even the foods, which are not the core of primary foods such as honey and milk because the peoples become more aware to choose healthy life style. Therefore, during pandemic, having enough foods to meet such healthy life style becomes the main expectation of the consumers. Honey becomes to be the top product that supports the aspect of human health because it belongs to food supplement. High demand but low purchasing power of the public has made the honey producers compete to get the market. There are many ways of marketing strategy to attract consumers such as low prices, best quality, great quantity, and uniqueness of the attributes on honey product. For reason of affordable purchasing power, a number of producers have produced synthetic (unoriginal) honeys, in which the basic substances are water and sugar that are easily found at marketplace in Indonesia. If so far most research are optimized to assist consumer in identifying content of the pure honey, therefore, in this research author assists the producers to present information for consumers about honey originality in the form of business transparency from upstream to downstream through traceability system and business improvement that support problem solutions from supply chain and its traceability.

Based on results of the research, there are 2 elements that relate to originality of the honey product in Tawon Rimba Raya Lawang (TRRL). They apply basic concept of food traceability. Those 2 elements were determined by the expert in accordance with result of FGD (Focus Group Discussion). The elements are distribution aspect and logistics. Provision of element becomes 
the reason for the expert to represent the main priority that needs to be studied more deeply due to distribution activities and logistics in TRRL are sensitive to originality level of the honey. The following are expert priority elements for originality assurance of honey and its importance:

Honey originality at distribution level is an effort of the producers to assure honey originality to consumers directly, both during promotions and referral consumer (selling optimization by involving customer journey system and assemble the potential buyer as well as advocating with satisfied customers about the TRRL products). The purpose is to increase trust whereas there is no marketing institution at distribution level which adds other material in honey product, so that its originality is assured.

Originality at logistic level means that producers assure and inform to consumers, directly as well as via promotion and attributes of the product whereas TRRL should have product flow organization system from upstream to downstream, protection for honey originality, and honey identification, so that all institution have data related to identity from the acquisition of raw materials to finished products. On packaging process, producers also assure that the packaging materials do not reduce the level of honey originality and protect it from contamination by other substances.

Following the acquisition of 2 assessment elements for honey originality, and the next 3 elements are the assessment priority for traceability at the level of stakeholders, distribution and logistics. What distinguishes between 2 elements of honey originality and 3 elements of traceability that are prioritized by experts to be an element of assessment if element of the product originality is focused on the responsibility of the producers toward originality at the downstream scope, while 3 experts traceability do not only focus on product flow activities, but also traceability of the actors and their activities to maintain integrity of the honey originality. The following are 3 elements of traceability stakeholders, distribution, and logistics :

Stakeholder traceability is originality assurance of honey with traceability method on actors who contribute to product flow started from procurement to the end user. Stakeholders do not only exist on downstream scope, but also all institutions who get involved in production and distribution of honey. The related stakeholders include the breeders, production division, marketing, agent and marketing institution who get involved in distributing the honey to consumers and finally to the end user. In traceability stakeholders, the actors play as verificator and guarantor for properness and originality of honey. 
Distribution traceability is traceability at distribution level, so that monitoring is carried out on the distribution flow of honey, starting from suppliers, marketing institutions, both agencies partnering with TRRL or marketing actors. The activities include tracing and tracking the data that starting from types of honey products, expired batches, product coding, identification of honey quality at the time before being handed over to marketing institutions and guaranteed by marketing institutions who distribute them. Objective of the distribution traceability activity is maintaining the honey value chain.

Logistic traceability is upstream-downstream activities which are intended to monitor product traceability that was carried out during logistics process. Logistics traceability is one of strategies, which is optimized by the producers to manage honey agribusiness activities starting from procurement, processing, storage, and product control accompanied with information and documentation by involving the managerial principle of TRRL supply chain. The traceability process does not only relate to product flow, but also understand the consumer behavior to produce products that meet the consumer expectations, so that it will be able to increase the consumer satisfaction.

\section{Activity of the Element as Honey Originality Assurance at Downstream Level}

In the research, optimization of tracking and tracing system are optimized at the downstream level due to high sensitivity to product originality. It is due to the involvement of marketing institutions as actor to assist producer in distributing the products to the end user as the producers are not able to reach the product which can be assured its originality. Therefore, information transparency is required to reach originality of the product for the end user. Responsibility of the marketing institution as distributor, for example the agency, is an effort to increase integrity of TRRL honey among products from the commercial brand even though its content is not pure, but the producer has an affordable price strategy in order to be affordable by the consumers, so that the consumers do not give priority to product originality. The following table presents the activities and responsibilities of actors on originality of honey at the downstream level : 
Traceability model system as originality ... (Jaisy Aghniarahim Putritamara, Rahmi Yuniarti, Anie Eka Kusumastuti)

Table 1. Activities of the actor at the downstream level

\begin{tabular}{|c|c|c|c|c|}
\hline Element & $\begin{array}{l}\text { Check Point } \\
\text { Activity }\end{array}$ & Information & Actor & Status \\
\hline $\begin{array}{l}\text { Originality on } \\
\text { distribution } \\
\text { process }\end{array}$ & $\begin{array}{l}\text { Content of } \\
\text { promotion, } \\
\text { customer journey } \\
\text { about amount } \\
\text { of supply and } \\
\text { demand }\end{array}$ & $\begin{array}{l}\text { Coding } \\
\text { product } \\
\text { information }\end{array}$ & Distributor & $\begin{array}{l}\text { Internal } \\
\text { and } \\
\text { external }\end{array}$ \\
\hline $\begin{array}{l}\text { Originality } \\
\text { on logistic } \\
\text { process }\end{array}$ & $\begin{array}{l}\text { attribute product } \\
\text { information } \\
\text { starting from } \\
\text { upstream, farm, } \\
\text { packaging } \\
\text { labeling, and } \\
\text { storage }\end{array}$ & $\begin{array}{l}\text { Coding } \\
\text { product } \\
\text { information }\end{array}$ & $\begin{array}{l}\text { Farmer, } \\
\text { manufactur- } \\
\text { er, distribu- } \\
\text { tor, retailer, } \\
\text { agency }\end{array}$ & $\begin{array}{l}\text { Internal } \\
\text { and } \\
\text { external }\end{array}$ \\
\hline $\begin{array}{l}\text { Stakeholders } \\
\text { traceability }\end{array}$ & $\begin{array}{l}\text { Data information } \\
\text { from all } \\
\text { stakeholders } \\
\text { (farmer, } \\
\text { processing actor, } \\
\text { marketer, agency, } \\
\text { retailer) }\end{array}$ & Recording data & & Internal \\
\hline $\begin{array}{l}\text { Distribution } \\
\text { traceability }\end{array}$ & $\begin{array}{l}\text { Data information } \\
\text { about attribute } \\
\text { of honey product } \\
\text { and their actors }\end{array}$ & $\begin{array}{l}\text { Coding } \\
\text { product } \\
\text { information }\end{array}$ & $\begin{array}{l}\text { All of } \\
\text { marketing } \\
\text { agency }\end{array}$ & $\begin{array}{l}\text { Internal } \\
\text { and } \\
\text { external }\end{array}$ \\
\hline $\begin{array}{l}\text { Logistic } \\
\text { traceability }\end{array}$ & $\begin{array}{l}\text { Data information } \\
\text { about all } \\
\text { agribusiness } \\
\text { activity from } \\
\text { upstream, } \\
\text { on farm also } \\
\text { downstream } \\
\text { and their actor } \\
\text { responsibility }\end{array}$ & $\begin{array}{l}\text { Coding } \\
\text { product } \\
\text { information }\end{array}$ & $\begin{array}{l}\text { Farmer, } \\
\text { manufactur- } \\
\text { er, distrubu- } \\
\text { tor, retailer, } \\
\text { agency }\end{array}$ & $\begin{array}{l}\text { Internal } \\
\text { and } \\
\text { external }\end{array}$ \\
\hline
\end{tabular}


Based on identification of element in accordance with activities and actors in Table 1 and continued with ISM analysis, the purpose is to obtain priority values, which are selected by the experts in accordance with element of honey originality and traceability. The following table presents relationship among variables that have been agreed by the expert in structural self interaction matrix (SSIM) model or it is so-called VAXO assessment matrix.

Table 2. SSIM for originality bee product and its traceability

\begin{tabular}{|c|c|c|c|c|c|c|}
\hline $\mathrm{No}$ & Element & A1 & $\mathrm{A} 2$ & A3 & A4 & A5 \\
\hline A1 & $\begin{array}{l}\text { Originality on distribution } \\
\text { process }\end{array}$ & $\mathrm{X}$ & $\mathrm{V}$ & $\mathrm{V}$ & $\mathrm{V}$ & $\mathrm{V}$ \\
\hline A2 & $\begin{array}{l}\text { Originality on logistics } \\
\text { process }\end{array}$ & & $\mathrm{X}$ & $\mathrm{V}$ & A & $\mathrm{X}$ \\
\hline A3 & Stakeholders traceability & & & $\mathrm{X}$ & A & A \\
\hline A4 & Distribution traceability & & & & $\mathrm{X}$ & V \\
\hline A5 & Logistics traceability & & & & & $\mathrm{X}$ \\
\hline
\end{tabular}

Table 2. SSIM informs that the experts determine relationship among variables that consist of $\mathrm{V}$ value, if the comparison of two variables where the row variable has a relationship with higher priority per level than the column variable. While A value is selected by the expert if the column variable becomes the main priority in comparison with the row variable. $\mathrm{X}$ value is selected by the expert if both variables are important and become the priority, and $\mathrm{O}$ value is selected if both variables have no correlation. The next analysis is determining the driving power and dependence as final reachability matrix test to acquire element from the superior to element that needs to be a top priority (because it has high dependence on other elements) as presented in Table 3 below.

Table 3. Final Reachbility Matrix (FRM)

\begin{tabular}{lllllllll}
\hline No & Element & A1 & A2 & A3 & A4 & A5 & $\begin{array}{l}\text { Driving } \\
\text { Power }\end{array}$ \\
\hline A1 & $\begin{array}{l}\text { Originality on distribution } \\
\text { process }\end{array}$ & 1 & 1 & 1 & 1 & 1 & 5 & 1 \\
A2 & Originality on logistics process & 0 & 1 & 1 & 0 & 1 & 3 & 3 \\
A3 & Stakeholders traceability & 0 & 0 & 1 & 0 & 0 & 1 & 4 \\
A4 & Distribution traceability & 0 & 1 & 1 & 1 & 1 & 4 & 2
\end{tabular}




\begin{tabular}{llllllll} 
A5 Logistics traceability & 0 & 1 & 1 & 0 & 1 & 3 & 3 \\
\hline Dependences Power & 1 & 4 & 5 & 2 & 4 & & \\
L & 4 & 2 & 1 & 3 & 2 & & \\
\hline
\end{tabular}

Based on result of reachability analysis, the key element that play great role is the higher driver power namely originality of honey product at distribution level by code A1. It shows that downstream activities, which determine consumer trust, are keeping the product originality at the distribution level. Distributor has a strategy in which its content is adjusted with the customer journey, so that it will create a marketing strategy that conforms to the consumer needs based on originality of the product. This way is more adaptive due to the designed strategy is adjusted to the condition of the consumers. TRRL has a recording strategy that facilitates the actors at the downstream level to tracking and tracing the honey product.

The next analysis is MICMAC quadrant, which is intended to study the impact of each variable on other variables, so that the experts will be able to determine priority of the built strategy. The following chart is MICMAC quadrant based on result of priority for elements, which are selected by the experts in the analysis of originality and traceability for TRRL honey. MICMAC analysis has 4 quadrants that include driver independent, linkage, autonomous and dependent. The independent variables have power to affect other variables but independent to other variables. Linkage variables have great power to affect other variables but have high dependence upon other variables. Autonomous variables do not have high influence and also do not have high dependence. Dependent variables have low effect and high dependency on other variables. The analysis results of MICMAC are presented in Figure 1 as follow.

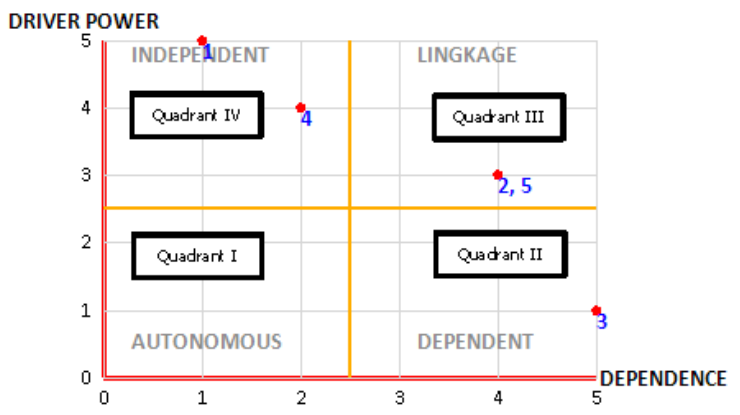

Figure 1. MICMAC analysis of honey originality and its traceability 
Based on the analysis result of MICMAC, the element 3, stakeholders traceability is in quadrant II or dependent, which means that this element does not have any power to affect other elements, but this element has high dependence upon other elements for originality assurance of honey product and its traceability. It indicates that actors who play in originality assurance of honey product started from upstream to downstream depend on SOP TRRL to guarantee that they sell original honey. If other elements such as originality assurance in distribution level, logistics and distribution traceability and logistics are successful in supporting originality process and its traceability, so that the stakeholders traceability will give good contribution to originality assurance of honey. Element 2 is originality assurance for honey in logistics level and element 5 is traceability logistics are both in quadrant III, which mean that both elements do not only have high power to affect other elements, but also have high dependency. The logistics success started from procurement, breeding, processing, and manufacturing as efforts to increase consumer trust through originality transparency by recording to guarantee the original honey and bring about great impact in distribution level and the stakeholders will be able to convince the consumer that it is the original honey. However, the logistics aspect depends on distribution element because the success of distribution will affect the success of logistics. Elements 1 and 4 are in quadrant 4 , which means that distribution aspect has very great impact, but it does not depend on other aspects of both stakeholders and logistics, because distribution level is determinant of success in which distributors directly deal with consumers who basically understand the needs and wants of the consumers.

Distribution process is a set of activities to fulfill the consumer needs. So that the producer ensures that the process of distributing the product to the end user is carried out properly, and supported by logistics outbound process, therefore quality and quantity of the product conform to the consumer expectations (Cecilia, 2010)

Based on the concept of supply chain management, the main objective of logistics distribution is to optimize value to increase the product value chain from upstream to downstream (Chopra and Meindl, 2001).

The analysis result of MICMAC below shows structuring level of honey originality elements and traceability as follow. 


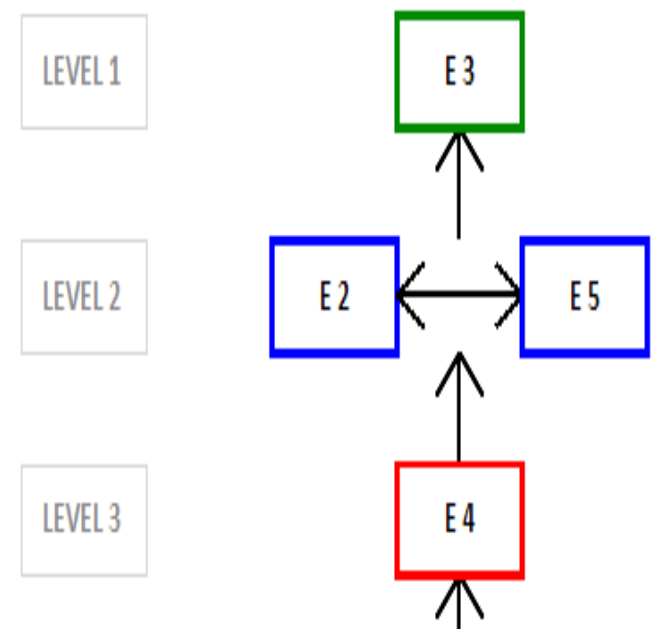

Figure 2. Structuring the element of honey originality and its traceability

Based on structuring the element in Figure 2, stakeholder traceability highly depends on logistics and distribution system, as well as its traceability, so that TRRL requires a recording management to monitor the actor's activities in supply chain management. For elements in dependency sector, it will establish a mutually beneficial and mutually influencing ecosystem business among elements for quadrant IV (originality on distribution and distribution traceability) as distribution aspect against quadrant III (originality on logistics process and logistics traceability) as logistics aspect. If both have strong strategy, so that they will directly improve the stakeholder traceability system. So far, CV TRRL has not had database retailer that remarket TRRL honey to the end user, therefore, elements in quadrant I determine the success of other elements in quadrant II and III, if the distribution aspect has positive impact, so that the logistics aspect and stakeholders will give good contribution to originality assurance of honey product from traceability system.

The producer gives priority to distribution problem as essential element in increasing product competitiveness. Based on logistics management inbound and outbound where cost and relevance analysis, planning, technical and service evaluation are efforts for distribution improvisation. The existence of such optimization has made the producer to have opportunity to achieve competitive advantage (Saremi H. and Mosavi S. 2014).

The chart below presents the business process model notation analysis with bizaggi modeler, which is designed to create appropriate distribution 
system for TRRL condition in facing the consumer doubts about originality of honey product.

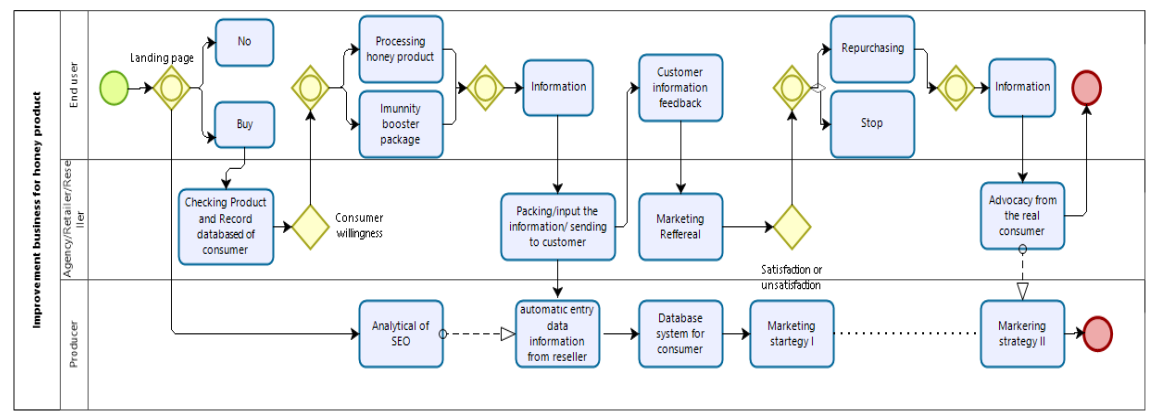

Figure 3. Business Process Notation for Improving Consumer Trust

Based on the analysis result of Business Process Notation using bizagi modeler, the strategy is optimized in distribution level (inbound logistics) because the relationship with consumer becomes closer to increase consumer trust in which TRRL product is original honey. Based on result of FGD with the expert, TRRL has not had referral marketing strategy, so that in BPMN chart, the author has designed a strategy that conforms to CV TRRL needs to improvise the business in the downstream level, particularly during the distribution process of honey.

\section{Conclusion}

The distribution element in CV TRRL is the strongest aspect that could affect logistic aspect and stakeholders in originality assurance of honey product, but it is not affected by the change of both affected elements. Therefore, optimization of distribution aspect is required to improvise both elements by improving the business model to comprehend the consumer needs for honey by applying adaptive marketing strategy.

\section{Acknowledgement}

Special thanks to the Institute for Research and Community Service, 
Traceability model system as originality ... (Jaisy Aghniarahim Putritamara, Rahmi Yuniarti, Anie Eka Kusumastuti)

Universitas Brawijaya, for the assistance of the Grant Scheme to the Novice Researcher in 2021.

\section{References}

Arifah, N. (2020). Manajemen perubahan dalam mewujudkan madrasah berprestasi. Jurnal Ilmu Pendidikan. 4(1). 57-70. https://doi.org/10.52431/ murobbi.v4i1.235

Bahadori, M., Teymourzadeh, E., Tajik, H., Ravangard, R., Raadabadi, M., \& Hosseini, S. M. (2018). Factors affecting strategic plan implementation using interpretive structural modeling (ISM). International journal of health care quality assurance. 31(5).406-414. https://doi.org/10.1108/ IJHCQA-05-2017-0075

Banwet, M, N, F, D, K. \& Shankar,R. (2006). Supply chain risk mitigation: Modeling the enablers. Bussiness Process Management Journal. 12(4),535552.

Bappenas, BPS \& UNFPA. (2018). Proyeksi penduduk Indonesia 2015-2045: Hasil SUPAS 2015. BPS.

Cecilia S, G. (2010). Importance of reverse logistics for retail. The Bucharest Academy of Economic Studies Romania.

Chopra S \& Meindl P. (2001). Supply chain management: Strategy, planning, and operation. Prentice-Hall. Inc.

Davison, R., Martinsons, M. G., \& Kock, N. (2004). Principles of canonical action research. Information systems journal, 14(1), 65-86. http://citeseerx.ist.psu. edu/viewdoc/download?doi=10.1.1.466.190\& $\mathrm{rep}=\mathrm{rep} 1 \&$ type=pdf

Gardas, B., Raut, R., Jagtap, A. H., \& Narkhede, B. (2019). Exploring the key performance indicators of green supply chain management in agroindustry. Journal of Modelling in Management. 14(1). 260-283. https:// doi.org/10.1108/JM2-12-2017-0139

Handayani DI. (2014). Risiko rantai pasok minuman sari apel dalam perspektif sistem traceability. J@ti Undip: Jurnal Teknologi Industri. 9(1). 57-68. https:// doi.org/10.12777/jati.9.1.57-68

Iwan, V. (2017). Halal traceability system pada supply chain makanan. Catatan Scl.

Kementerian Perdagangan. (2015). Market brief produk perikanan di Hongaria. Kementerian Perdagangan.

Kotler, P \& Keller, K,L. (2012). Marketing manajemen edisi keempat belas. Pearson 
Journal of Social Studies (JSS), Volume 17, Number 2, 2021: 221-240

Prentice Hall, Inc

Nurmalia, N. \&Nurani, F. (2019). Strategi kepemimpinan dalam perubahan ekonomi G-20. Administrasi Publik, Fakultas Ilmu Administrasi., Universitas Brawijaya. 1-12.

Olsen, P., \& Borit, M. (2013). How to define traceability. Trends in food science $\mathbb{E}$ technology, 29(2), 142-150. doi:10.1016/j.tifs.2012.10.003

Pfohl, H. C, Gallus, P.,\& D. Thomas. (2011). Interpretive structural modeling of supplychain risks. InternasionalJournal Phys. Distribution Logistic Management. 41(9). 839-859. https://doi.org/10.1108/09600031111175816

Saremi H. \& Mosavi S. (2014). Management of distribution channels.

Schiffman, L. G. \& Wisenblit, J. L. (2015). Consumer behavior edisi 11 global edition. Pearson Education Limited

Wisenblit, L. G. S. dan J. L. (2015). Consumer behavior. Pearson Education.

Yang, Y\& Bao,W. (2011). The design and implementation of halal beef wholly quality traceability system. dalam Computer and Computing Technologies in Agriculture IV, in D Li, YLiu \& Y Chen (eds), Springer, vol. 346, Boston,464-472.

Yin, k,R. (2003). Studi kasus, desain, dan metode. PT Grafindo Persada.

Yohana, N. D. \& Marisa,F. (2018). Perancangan proses bisnis sistem human resource management (HRM) untuk meningkatkan kinerja pegawai. JIMF: Jurnal Informatika Merdeka Pasuruan. 3(2). 23-32. 